\title{
Depresyon Tanısı Alan Hastalarda Çocukluk Çağı Travması Varlığı ve Duygu Düzenleme Güçlüğü İle İlișkisi
}

\author{
Rukiye AY 國, Oğuzhan KILINÇEL [ id ${ }^{2}$
}

Öz

Amaç: Bu çalışmada depresyon hastalarında çocukluk çağı travması varlığı ve duygu düzenleme güçlüğü ile ilişkisinin araştırılması amaçlanmıştır.

Gereç ve Yöntemler: Kesitsel tipte olan araştırma Haziran 2020 - Ekim 2020 tarihleri arasında Sakarya Yenikent Devlet Hastanesi Psikiyatri Polikliniğine başvuran, takip ve tedavileri sürdürülen DSM-5 kriterlerine göre depresif bozukluk tanısı konulan hastalardan çalışma kriterlerini karşılayan 63 hasta ve rastgele seçilen benzer sosyodemografik özelliklere sahip 65 sağlıklı birey ile gerçekleştirilmiştir. Veriler Kişisel Bilgi Formu, Beck Depresyon Ölçeği (BDÖ), Çocukluk Çağı Travma Ölçeği (CTQ) ve Duygu Düzenleme Güçlüğü Ölçeği (DERS) kullanılarak toplanmıştır. Verilerin analizi; tanımlayıc istatistikler, Mann Whitney U testi, Ki-kare testleri ve Spearman korelasyon analizi ile değerlendirilmiştir.

Bulgular: Yaş ortalaması 31,48 \pm 9,47 (18-61) olan çalışmada, depresyon hastalarında sağlıklı bireylere kıyasla çocukluk çağı travma anketi puanlarının (cinsel istismar alt boyutu hariç) ve duygu düzenleme gü̈clüğü ölçeği puanlarının yüksek olduğu tespit edilmiştir. Bununla birlikte Depresyon hastalarında CTQ toplam puanı CTQ $\geq 35$ olanlarda BDÖ ve DERS stratejiler, dürtüsellik, amaçlar alt boyutları ile toplam puanlarının yüksek olduğu saptanmıştır. Ayrıca CTQ toplam puanı ile DERS kabullenme, stratejiler, amaçlar alt boyutları ile toplam puanları arasında pozitif anlamlı ilişki saptanmıştır.

Sonuç: Çocukluk çağı travmalarına maruz kalma durumunun mevcut depresyonla ilişkili olduğu ve bu durumun duygu düzenlemede güçlüklere neden olduğu belirlenmiştir.

Anahtar Kelimeler: Depresyon; travma ve stresör ilişkili bozukluklar; cinsel istismar.

\section{The Presence of Childhood Trauma in Depression Patients and Its Relationship with Difficulties Emotion Regulation}

\begin{abstract}
Aim: In this study, it was aimed to investigate the relationship between the presence of childhood trauma and difficulty in emotion regulation in patients with depression.

Material and Methods: The cross-sectinoal study was conducted with 63 patients who were diagnosed with depressive disorder according to DSM-5 criteria, who applied to Sakarya Yenikent State Hospital Psychiatry Outpatient Clinic between June 2020 and October 2020, and who were diagnosed with depressive disorder according to DSM-5 criteria and 65 healthy individuals randomly selected with similar sociodemographic characteristics. Data were collected using the Personal Information Form, Beck Depression Inventory (BDI), Childhood Trauma Scale (CTQ), and Emotion Regulation Difficulty Scale (DERS). The data were evaluated using descriptive statistics, Mann Whitney U test, Chisquare tests and Spearman correlation analysis.

Results: In the study with a mean age of $31.48 \pm 9.47$ (range 18 to 61), it was found that childhood trauma questionnaire scores (excluding sexual abuse sub-dimension) and emotion regulation difficulty scale scores were higher in depression patients compared to healthy individuals. On the other hand, it was found that the BDI and DERS strategies, impulsivity, goals sub-dimensions and total scores were higher in patients with depression patients whose
\end{abstract}

1 Bursa Yüksek İhtisas Eğitim Araştırma Hastanesi, Psikiyatri Kliniği, Bursa, Türkiye 2 Sakarya Yenikent Devlet Hastanesi, Psikiyatri Kliniği, Sakarya, Türkiye 
CTQ total score was CTQ $\geq 35$. In addition, a positive significant relationship was found between CTQ total score and DERS acceptance, strategies, goals subdimensions and total scores.

Conclusion: It has been determined that exposure to childhood traumas is related to current depression and this situation causes difficulties in emotion regulation.

Keywords: Depression; trauma and stressor related disorders; sexual abuse.

\section{GíRIS}

Majör depresif bozukluk (MDB), Dünya Sağlık Örgütü'ne göre dünya çapında 300 milyondan fazla insanın etkileyen, yaygın psikiyatrik bozukluktur (1). Depresif bozukluk da dahil olmak üzere, duygu durum bozuklukları patogenezinde genetik yatkınlık, epigenetik düzenleme ve çevresel etkileri içeren bir gen-çevre etkileşimi modeli ileri sürülmektedir (2). Psikiyatrik bozuklukların oluşumunda en önemli çevresel belirleyicisi olarak çocukluk çağı travmaları kabul edilmektedir. Erken dönemlerde yaşanan stres ve ihmal genomik özelliklerle etkileşime girerek nörogelişimi değiştirebildiği öne sürülmüştür (3). Travma sonrası stres bozukluğu, depresif bozukluk, anksiyete bozukluğu, kişilik bozuklukları, alkol ve madde bağımlılığı, duygudurum bozuklukları, disosiyatif bozukluklar, psikotik bozukluklar, obsesif kompulsif bozukluk gibi birçok psikiyatrik bozukluk çocukluk çağı travmalarının uzun dönem sonuçları arasında görülmektedir (4-6).

Çocuk istismarı ve ihmali, ana baba ya da bakıcı gibi bir erişkin tarafından çocuğa yöneltilen, toplumsal kurallar ve profesyonel kişilerce uygunsuz ya da hasar verici olarak nitelendirilen, çocuğun gelişimini engelleyen ya da kısıtlayan eylem ve eylemsizliklerin tümüdür. Bu eylem ya da eylemsizliklerin sonucu olarak çocuğun fiziksel, ruhsal, cinsel ya da sosyal açıdan zarar görmesi, sağlık ve güvenliğinin tehlikeye girmesi söz konusudur (7). Fiziksel istismar, bir kişinin 18 yaşından önce, kendisinden en az 5 yaş büyük bir kişi ya da kendisinden 2 yaş büyük bir aile bireyi tarafından kaba kuvvete uğramasıdır (8). Duygusal istismar, çocuğun ruhsal sağlığını olumsuz yönde etkileyecek düzeyde alay edilme, aşağılanma, küçük düşürücü yorumlarda bulunma veya ağır sözel tehdit alma şeklinde tanımlanmıştır (9). Cinsel istismar; henüz psikososyal gelişimini tamamlamamış çocuğun, kendisinden en az altı yaş büyük biri tarafindan cinsel arzu ve gereksinimlerini karşılamak amacıyla tehdit etme, güç kullanma veya kandırma yoluyla kullanılmasıdır (7). Fiziksel ihmal, çocuğun temel ihtiyacı olan yeterli besin, giyecek, güvenli ve denetimli ortamı sağlayamamayı içerir. Çocuğu terk etmek te fiziksel ihmale girmektedir (10). Duygusal ihmal, çocuğun psikolojik ihtiyaçlarını ve duygusal gereksinimlerini karşılamama, sosyal kuralları öğretmeme ve çocuğun sosyal gelişimini sağlayacak destekleyici ilgiyi göstermeme ile tanımlanır (11).

Depresif bozuklukta çocukluk çağı travmalarının olumsuz sonuçlarıyla mücadele edebilmek için travmatik deneyim ve psikopatoloji arasındaki mekanizmanın anlaşılmasının önemli olduğu düşünülmektedir. Duygu düzenlemenin çocukluk çağı travmaları ve depresyon arasındaki ilişkide önemli bir rol oynadığını göstermektedir (12). Adaptif duygu düzenleme stratejileri akademik başarı sosyal işlevsellik, yetişkinlikte psikolojik ve fiziksel iyilik ile bağlantılı olduğu ifade edilmiştir (13). Duygu düzenlemede yaşanan güçlük; duygusal farkındalık eksikliği, duygusal açıklık eksikliği, duygusal tepkileri kabul etmeme, duygu düzenleme stratejilerini etkili kullanmama, dürtü kontrol güçlükleri ve hedefe yönelik davranışta bulunmada güçlük bileşenleri ile açıklanmıştır (14). Duygu düzenleme güçlüğünün depresyon, bipolar bozukluk, kişilik bozuklukları, madde kötüye kullanımı, yeme bozukları, dikkat eksikliği ve aktivite bozukluğu, travma sonrası stres bozukluğu ve somotoform bozukluklar gibi birçok psikopatolojinin gelişmesinde, sürmesinde ve tedavisinde rol oynadığı bildirilmiştir (15). Özellikle çocukluk çağında maruz kalınan duygusal, fiziksel, cinsel travmalar duygu düzenleme güçlükleri için başlica etken (determinants) olmasının yanı sıra depresyon ve travma sonrası stres bozukluğu gibi psikiyatrik bozukluklar için risk faktörü olduğu ileri sürülmüştür (16). Çalışmamızda depresyon hastalarında çocukluk çağı travması varlığı ve duygu düzenleme güçlüğü ile ilişkisinin araştırılması amaçlanmıştır.

\section{GEREÇ VE YÖNTEMLER}

Araştırmanın Türü

Çalışma kesitsel bir araştırma olarak gerçekleştirilmiştir.

Araştırmanın Yeri ve Zamanı

Araştırmaya Haziran 2020 - Ekim 2020 tarihleri arasında

Sakarya Yenikent Devlet Hastanesi Psikiyatri Polikliniğine başvuran, takip ve tedavileri sürdürülen DSM-5 kriterlerine göre depresif bozukluk tanısı konulan hastalardan çalışma kriterlerini karşılayan hastalar dahil edilmiştir.

\section{Araştırmanın Örneklemi}

Çalışmanın örneklem büyüklüğü için Weiss ve ark. (15) çalışmasında travma ve kontrol gruplarına uygulanan ölçeklerin ortalama ve standart sapmalarının karşılaştırılması referans alınarak (Duygudurum düzenleme zorlukları ölçeği sırasıyla travma 17,18 $\pm 5,83$ ve kontrol $13,94 \pm 1,89) \% 80$ güç ve 0,05 anlamlılık düzeyi ile her bir gruba alınması gereken hasta sayısının 51 olduğu hesaplanmıştır. $\mathrm{Bu}$ amaçla psikiyatri polikliniğinde takipli olup, depresif bozukluk tanısı alan hastalar taranmış ve çalışmaya katılmaya gönüllü olan 18-65 yaş arası hastalar dahil edilmiştir. Mental retardasyonu olan, bilişsel işlevleri etkileyecek nörolojik ya da sistemik hastalığa sahip olan hastalar çalışmadan dışlanmıştır. Toplamda 63 hastaya ulaşılmış ve hastalar ile benzer sosyodemografik özelliklere sahip (hastane çalışanları ve yakınları) 65 bireyin verileri ile karşılaştırılmıştır.

\section{Veri Toplama Araçları}

Sosyodemografik ve klinik özellikler değerlendirme formu: Katılımcıların sosyodemografik özelliklerini belirlemek için bu çalışmada kullanılmak üzere araştırmacılar tarafından geliştirilmiş yaş, cinsiyet, medeni durum, eğitim durumu, çalışma durumu, intihar girişim öyküsü, ilaç kullanımı gibi soruları içeren soru formudur.

Beck Depresyon Ölçeği (BDÖ): Depresyonun duygusal, bilişsel, somatik ve motivasyonel bileşenlerini ölçmek amacıyla Beck tarafından 1961 'de geliştirilmiş bir özbildirim ölçeğidir (17). '0' ile '3' arasında derecelendirilen dörtlü Likert tipinde cevaplanan 21 
maddeden oluşmaktadır. Testten en düşük $O$, en yüksek 63 puan alınabilir. Depresyonun şiddeti 4 derecede değerlendirilir; 5-9 puanlar arası sağlıklı, 10-18 puanlar arası hafif-orta, 19-29 puanlar arası orta-şiddetli ve 30-63 puanlar arası şiddetli depresyonu belirlemektedir. Ülkemizde üniversite öğrencileri için geçerlilik ve güvenilirlik çalışmasında kesme puanının 17 olarak kabul edildiği bildirilmiştir (18).

Beck Anksiyete Ölçeği (BAÖ): Beck Anksiyete Ölçeği (BAÖ), Beck ve ark. (19) tarafından 1988 yılında geliştirilmiştir. 19 bireyin yaşadığı anksiyete belirtilerinin sıklığını ölçmek için bedensel ve öznel anksiyete belirtilerini içeren 21 maddeden oluşan, 0-3 arası puanlanan likert tipi bir ölçektir. Her bir madde için "Hiç", "Hafif derecede", "Orta derecede" ve "Ciddi derecede" seçenekleri bulunmaktadır. Bireyin yaşadığ 1 anksiyete belirtilerinin sıklığını değerlendirmektedir. Hastaya sorulan sorularla sıkıntı hissinin onu son bir haftadır ne kadar rahatsız ettiği sorgulanır. Ölçekten alınabilecek en düşük puan 0, en yüksek puan ise 63'dür Türkçe geçerlilik ve güvenilirlik çalışması, Ulusoy ve ark. (20) tarafindan 1998 yılında klinik hastalar ile yapılmış ve ölçeğin iç tutarlılık katsayısı 0,93 olarak bulunmuştur.

Çocukluk Çağı Travma Ölçeği (CTQ-28): Bernstein ve ark. (21) 1994 yılında geliştirdiği, beşli Likert tipi özbildirim ölçeğidir. Duygusal istismar, fiziksel istismar, cinsel istismar, duygusal ihmal ve fiziksel ihmal olarak 5 alt ölçeği bulunan ölçek maddeleri 1-5 arasında puanlanmaktadır. Ölçeğin 28 soruluk formunun Türkçe'ye adaptasyon, geçerlilik ve güvenilirlik çalışmasında cinsel ve fiziksel istismar için 5 puanın üzeri, fiziksel ihmal ve duygusal istismar için 7 puanın üzeri, duygusal ihmal için 12 puanın üzeri, toplam puan için ise 35 puanın üzeri kesme noktası olarak önerilmiştir (22). Ölçeğin iç tutarlılığını gösteren Cronbach alfa değeri 0,93 ve Gutmann yarım test katsayısı ise 0,97 olarak bildirilmiştir (22).

Duygu Düzenleme Güçlüğü Ölçeği (DERS): Gratz ve Roemer (14) tarafindan geliştirilen Duygu Düzenleme Güçlüğü Ölçeği (DERS); duygusal tepkilere ilişkin farkındalığın olmaması (farkındalık), duygusal tepkilerin anlaşılmaması (açıklık), duygusal tepkilerin kabul edilmemesi (kabul etmeme), etkili olarak algılanan duygu düzenleme stratejilerine sınırlı erişim (stratejiler), olumsuz duygular deneyimlerken dürtülerin kontrolünde güçlük yaşama (dürtü), olumsuz duygular deneyimlerken amaç odaklı davranışlarda bulunmada güçlük yaşama (amaçlar) alt boyutları altında toplanan 36 maddeden oluşmaktadır (14). Kendini bildirime dayanan beşli likert tipi ölçüm sağlamaktadır. Ölçek için kesme puanı belirlenmemiş olmakla birlikte yüksek puanlar daha şiddetli duygu düzenleme güçlüğünün varlığına işaret etmektedir. Ö̉çeğin özgün formunda iç tutarlık katsayısı 0,93 olarak bulunmakla birlikte alt boyutlarına ilişkin iç tutarlık katsayılarının 0,88 ile 0,89 arasında değiştiği, test-tekrar test güvenirliğinin ise 0,88 olduğu bildirilmiştir (14). Ölçeğin Türkçe formunun psikometrik özellikleri ilk olarak Rugancı ve Gençöz (23) tarafından çalışılmıştır. Türkçe uyarlamasından elde edilen sonuçlarda, ölçeğin Cronbach Alfa iç tutarlılık katsayısı 0,94 olarak bulunmuştur. Alt boyutlarının iç tutarlılık kat sayıları ise 0,75 ile 0,90 arasında değişmektedir. DERS' in test-tekrar test güvenirliği 0,83, Guttman yarıya bölme güvenirlik katsayısı 0,95'tir (23).

\section{Araştırmanın Etik Yönü}

Araştırma projesi Sakarya Üniversitesi Tıp Fakültesi Girişimsel Olmayan Klinik Araştırmalar Etik Kurulu tarafindan onayland $\quad$ (Tarih:20/05/2020, Onay no:71522473/050.01.04/259). Helsinki Deklerasyonu Prensipleri'ne uyulmuştur. Araştırmada gönüllülük ilkesi ön planda tutularak araştırmaya katılmayı kabul eden katılımcılardan bilgilendirilmiş onam alınmıştır.

\section{İstatistiksel Analiz}

Tüm analizler SPSS v21 (SPSS Inc., Chicago, IL, ABD) üzerinde yapıldı. Normallik kontrolü için analitik testlerden Kolmogorov-Smirnov testi kullanıldı. Sürekli değişkenler için medyan (1. ve 3. çeyrekler) değerleri ve kategorik değişkenler için frekans (yüzde) değerleri gösterilmiştir. Normal dağılım göstermeyen gruplar arasında sürekli değişkenler Mann Whitney U testi ile analiz edildi. Kategorik değişkenler Pearson Ki-kare testi veya Fisher'in kesin testi ile analiz edildi. Sürekli değişkenler normal dağılıma uymadığı gözlendi ve aralarındaki ilişkileri değerlendirmek için Spearman korelasyon katsayıları hesaplandı. $\mathrm{p}<0,05$ değerleri istatistiksel olarak anlamlı sonuç olarak kabul edildi.

\section{BULGULAR}

Çalışmaya hasta grubuna 63 ve kontrol grubuna 65 olmak üzere toplam 128 olgu dahil edildi. Yaş ortalaması 31,48 $\pm 9,47$ (minimum 18 - maksimum 61) idi. Hasta grubu ve kontrol grubu arasında yaş, cinsiyet ve medeni durum bakımından istatistiksel olarak anlamlı farklılık bulunmad1 $(\mathrm{p}>0,05)$. Hasta grubunda kontrol grubuna göre eğitim durumu istatistiksel olarak anlamlı derecede daha düşüktü $(\mathrm{p}<0,01)$. Kontrol grubunda öğrenci yüzdesi anlamlı olarak yüksek iken, çalışma yüzdesi hasta grubunda anlamlı olarak yüksekti $(p<0,01)$. Hasta grubunda beş $(\% 7,94)$ kişinin intihar girişimi öyküsü, kontrol grubunda ise iki $(\% 3,08)$ kişinin intihar girişimi öyküsü vardı. Medikal tedavi için $17(\% 26,98)$ hastaya antidepresan ve bir $(\% 1,59)$ hastaya antidepresan + antipsikotik verildi.

Beck Depresyon Ölçeği (BDÖ) puanı, Beck Anksiyete Ölçeği (BAÖ) puanı, Duygu Düzenleme Güçlüğü Ölçeği (DERS) toplam ve tüm alt ölçek puanları, Çocukluk Çağı Travma Anketi (CTQ) duygusal istismar, fiziksel istismar, duygusal ihmal, fiziksel ihmal ve toplam puanlar hasta grubunda kontrol grubuna göre anlaml derecede yüksekti $(p<0,05)$ (Şekil 1-2). CTQ cinsel istismar puanları açısından gruplar arasında anlamlı bir fark yoktu. Ayrica hasta grubunda $39(\% 61,90)$ birey 35 ve üzeri CTQ toplam puanına sahipken, kontrol grubunda $15(\% 23,08)$ kişi 35 ve üzeri CTQ toplam puanına sahipti (Tablo 1)

Hastaları CTQ toplam puanlarına göre iki gruba ayırdık (35'in altında ve 35 veya üstünde). CTQ $\geq 35$ olanlarda CTQ $<35$ olanlara göre BDÖ ve DERS stratejiler, dürtüsellik, amaçlar alt boyutları ile toplam puanları istatistiksel olarak anlamlı derecede daha yüksek saptandı $(p<0,05)$. CTQ grupları arasında yaş, cinsiyet, eğitim durumu, çalışma durumu, medeni durum, intihar girişimi, ilaç tedavisi, BAÖ puanları, DERS farkındalık, açıklık ile kabullenme alt boyut puanları bakımından istatistiksel olarak anlamlı farklılık yoktu (Tablo 2). 
Tablo 1. Gruplara göre birey özelliklerinin ve envanter / ölçek / anket puanlarının karşılaştırılması

\begin{tabular}{|c|c|c|c|}
\hline & \multicolumn{2}{|c|}{ Gruplar } & \multirow[b]{2}{*}{$\mathrm{p}$} \\
\hline & Hasta $(n=63)$ & Kontrol (n=65) & \\
\hline \multicolumn{3}{|l|}{ Cinsiyet } & $0,637 *$ \\
\hline Kadın & $38(\% 60,32)$ & $41(\% 63,08)$ & \multirow{2}{*}{$0,748 * *$} \\
\hline Erkek & $25(\% 39,68)$ & $24(\% 36,92)$ & \\
\hline \multicolumn{4}{|l|}{ Eğitim } \\
\hline İlköğretim & $15(\% 23,81)$ & $2(\% 3,08)$ & \multirow{3}{*}{$\mathbf{0 , 0 0 1} * *$} \\
\hline Lise & $22(\% 34,92)$ & $19(\% 29,23)$ & \\
\hline Yüksek lisans/Lisans & $26(\% 41,27)$ & $44(\% 67,69)$ & \\
\hline \multicolumn{4}{|l|}{ Çalışma durumu } \\
\hline Çalışmıyor & $24(\% 38,10)$ & $29(\% 44,62)$ & \multirow{3}{*}{$0,001 * * *$} \\
\hline Öğrenci & $13(\% 20,63)$ & $36(\% 55,38)$ & \\
\hline Çalışıyor & $26(\% 41,27)$ & $0(\% 0,00)$ & \\
\hline \multicolumn{4}{|l|}{ Medeni durumu } \\
\hline Bekar & $28(\% 44,44)$ & $32(\% 49,23)$ & \multirow{2}{*}{$0,587 * *$} \\
\hline Evli & $35(\% 55,56)$ & $33(\% 50,77)$ & \\
\hline İntihar girişimi & $5(\% 7,94)$ & $2(\% 3,08)$ & $0,270 * * *$ \\
\hline \multicolumn{4}{|l|}{ İlaç tedavisi } \\
\hline Yok & $45(\% 71,43)$ & - & \multirow{3}{*}{-} \\
\hline Antidepresan & $17(\% 26,98)$ & - & \\
\hline Antidepresan + Antipsikotik & $1(\% 1,59)$ & - & \\
\hline BDÖ puanı & $22(15-28)$ & $9(7-12)$ & $<0,001 *$ \\
\hline BAÖ puanı & $20(12-30)$ & $10(8-12)$ & $<0,001 *$ \\
\hline \multicolumn{4}{|l|}{ DERS puanı } \\
\hline Farkındalık & $17(12-20)$ & $13(11-15)$ & $<0,001 *$ \\
\hline Açıklık & $13(10-17)$ & $9(7-12)$ & $<0,001 *$ \\
\hline Kabullenme & $14(11-20)$ & $10(8-12)$ & $<0,001 *$ \\
\hline Stratejiler & $24(20-31)$ & $15(10-18)$ & $<0,001 *$ \\
\hline Dürtüsellik & $17(13-23)$ & $11(7-14)$ & $<0,001 *$ \\
\hline Amaçlar & $19(15-22)$ & $12(9-14)$ & $<0,001 *$ \\
\hline Toplam & $108(88-124)$ & $69(59-81)$ & $<0,001 *$ \\
\hline \multicolumn{4}{|l|}{ CTQ puanı } \\
\hline Duygusal istismar & $8(5-11)$ & $5(5-8)$ & $<0,001 *$ \\
\hline Fiziksel istismar & $5(5-7)$ & $5(5-5)$ & $0,016 *$ \\
\hline Duygusal ihmal & $13(9-16)$ & $8(5-10)$ & $<0,001 *$ \\
\hline Fiziksel ihmal & $7(5-10)$ & $5(5-5)$ & $<0,001 *$ \\
\hline Cinsel istismar & $5(5-5)$ & $5(5-5)$ & $0,270^{*}$ \\
\hline Toplam & $38(33-46)$ & $29(26-34)$ & $<0,001 *$ \\
\hline \multicolumn{4}{|l|}{ CTQ toplam puanı } \\
\hline$<35$ & $24(\% 38,10)$ & $50(\% 76,92)$ & \multirow{2}{*}{$<0,001 * *$} \\
\hline$\geq 35$ & $39(\% 61,90)$ & $15(\% 23,08)$ & \\
\hline
\end{tabular}

Not: Veriler, dağılımın normalliğine göre sürekli değişkenler için medyan (1.çeyrek - 3.çeyrek) ve kategorik değişkenler için frekans (yüzde) olarak verilmiştir. Beck Depresyon Ölçeği (BDÖ) puanı, Beck Anksiyete Ölçeği (BAÖ) puanı, Duygu Düzenleme Güçlüğü Ölçeği (DERS) puanı, Çocukluk Çağı Travma Anketi (CTQ). İstatistiksel anlamlı farkı ifaden eden p değerleri kalın olarak gösterilmiştir.

*Mann-Whitney U testi **Pearson Ki-kare testi ***Fisher'1n kesin testi 
Tablo 2. CTQ toplam puanlarına göre hasta özellikleri ve envanter / ölçek puanlarının karşılaştırılması

\begin{tabular}{|c|c|c|c|}
\hline & \multicolumn{2}{|c|}{ CTQ toplam puanı } & \multirow[b]{2}{*}{$\mathrm{p}$} \\
\hline & $<35(\mathrm{n}=24)$ & $\geq 35(n=39)$ & \\
\hline Yaş & $31(24-42)$ & $27(23-41)$ & $0,407 *$ \\
\hline \multicolumn{4}{|l|}{ Cinsiyet } \\
\hline Kadın & $11(\% 45,83)$ & $27(\% 69,23)$ & \multirow{2}{*}{$0,065^{* *}$} \\
\hline Erkek & $13(\% 54,17)$ & $12(\% 30,77)$ & \\
\hline \multicolumn{4}{|l|}{ Eğitim } \\
\hline İlköğretim & $3(\% 12,5)$ & $12(\% 30,77)$ & \multirow{3}{*}{$0,238 * *$} \\
\hline Lise & $9(\% 37,5)$ & $13(\% 33,33)$ & \\
\hline Yüksek lisans/Lisans & $12(\% 50,00)$ & $14(\% 35,90)$ & \\
\hline \multicolumn{4}{|l|}{ Çalışma durumu } \\
\hline Çalışmıyor & $7(\% 29,17)$ & $17(\% 43,59)$ & \multirow{3}{*}{$0,505 * *$} \\
\hline Öğrenci & $6(\% 25,00)$ & $7(\% 17,95)$ & \\
\hline Çalışıyor & $11(\% 45,83)$ & $15(\% 38,46)$ & \\
\hline \multicolumn{4}{|l|}{ Medeni durumu } \\
\hline Bekar & $9(\% 37,50)$ & $19(\% 48,72)$ & \multirow{2}{*}{$0,384 * *$} \\
\hline Evli & $15(\% 62,50)$ & $20(\% 51,28)$ & \\
\hline İntihar girişimi & $1(\% 4,17)$ & $4(\% 10,26)$ & $0,641 * * *$ \\
\hline \multicolumn{4}{|l|}{ İlaç tedavisi } \\
\hline Yok & $14(\% 58,33)$ & $31(79,49 \%)$ & \multirow{3}{*}{$0,078 * * *$} \\
\hline Antidepresan & $10(41,67 \%)$ & $7(17,95 \%)$ & \\
\hline Antidepresan + Antipsikotik & $0(\% 0,00)$ & $1(\% 2,56)$ & \\
\hline BDÖ puanı & $19(11-26)$ & $24(18-32)$ & $\mathbf{0 , 0 3 2} *$ \\
\hline BAÖ puanı & $20(12,5-31)$ & $18(12-30)$ & $0,793 *$ \\
\hline \multicolumn{4}{|l|}{ DERS puanı } \\
\hline Farkındalık & $17(11-19)$ & $17(12-20)$ & $0,760 *$ \\
\hline Açıklık & $13(8-15,5)$ & $14(11-17)$ & $0,095 *$ \\
\hline Kabullenme & $13(8-20,5)$ & $16(12-20)$ & $0,152 *$ \\
\hline Stratejiler & $20,5(16-24)$ & $27(21-32)$ & $<0,001 *$ \\
\hline Dürtüsellik & $14,5(11-19)$ & $20(15-24)$ & $\mathbf{0 , 0 1 3} *$ \\
\hline Amaçlar & $17(13-20)$ & $21(17-24)$ & $\mathbf{0 , 0 0 3 *}$ \\
\hline Toplam & $93(82-112)$ & $113(96-130)$ & $\mathbf{0 , 0 0 2 *}$ \\
\hline
\end{tabular}

Not: Veriler, dağılımın normalliğine göre sürekli değişkenler için medyan (1.çeyrek - 3.çeyrek) ve kategorik değişkenler için frekans (yüzde) olarak verilmiştir. Beck Depresyon Ölçeği (BDÖ) puanı, Beck Anksiyete Ölçeği (BAÖ) puanı, Duygu Düzenleme Güçlüğü Ölçeği (DERS) puanı, Çocukluk Çağı Travma Anketi (CTQ). İstatistiksel anlamlı farkı ifaden eden p değerleri kalın olarak gösterilmiştir.

*Mann-Whitney U testi **Pearson Ki-kare testi ***Fisher'1n kesin testi

Sağlıklı bireyleri CTQ toplam puanlarına göre iki gruba ayırdık (35 altı ve 35 ve üstü). CTQ $\geq 35$ olanlarda CTQ $<35$ olanlara göre BDÖ puanları, BAÖ puanları, DERS farkındalık, açıklık, kabullenme, stratejiler, dürtüsellik, amaçlar ve toplam puanları istatistiksel olarak anlamlı derecede daha yüksek saptand $1(\mathrm{p}<0,05)$. CTQ grupları arasında yaş, cinsiyet, eğitim durumu, çalışma durumu, medeni durum, intihar girişimi açısından anlamlı farklılık yoktu (Tablo 3).

Hasta grubunda yaş ile BDÖ, yaş ile BAÖ, yaş ile DERS açıklık alt boyut, yaş ile DERS kabullenme alt boyut, yaş ile DERS stratejiler alt boyut, yaş ile DERS dürtüsellik alt boyut, yaş ile DERS amaçlar alt boyut, yaş ile CTQ duygusal istismar alt boyut puanları arasında negatif yönde zayıf derecede istatistiksel olarak anlamlı korelasyon bulundu. Yaş ile DERS toplam puan arasında negatif yönde orta derecede istatistiksel olarak anlamlı korelasyon bulundu. Bununla birlikte BDÖ ile CTQ toplam puan, BDÖ ile CTQ duygusal istismar alt boyut puanı, BAÖ ile DERS toplam puan, BAÖ ile CTQ cinsel istismar alt boyut puan1, DERS toplam ile CTQ toplam puan1, DERS toplam ile CTQ duygusal ihmal alt boyut puan1, DERS toplam ile CTQ cinsel istismar alt boyut puanı arasında pozitif yönde zayıf derecede istatistiksel olarak anlamlı korelasyon bulundu. BAÖ puanları ile farkındalık, kabullenme, stratejiler, dürtüsellik, amaçlar ve toplam puan ile pozitif korelasyon gösterdiği tespit edildi. Tablo 4'te hasta grubunun CTQ, BDÖ, BAÖ ölçekleri arasındaki korelasyonlar gösterilmiştir. 


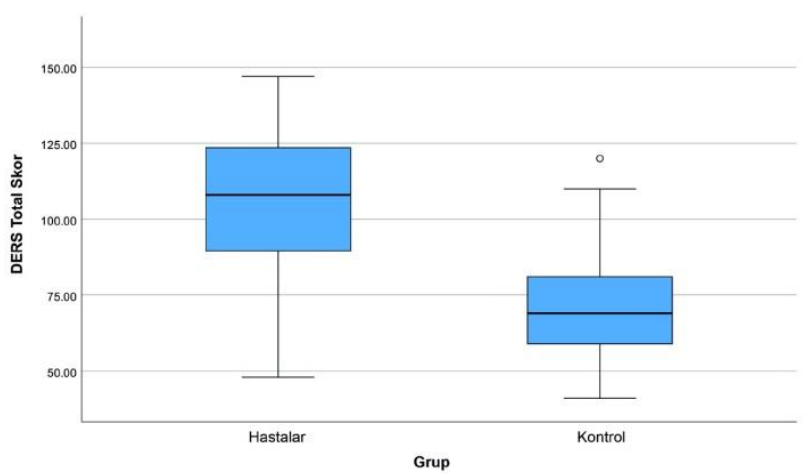

Şekil 1. Gruplara göre Duygu Düzenleme Güçlüğü Ölçeği (DERS) toplam puanlar

Tablo 3. CTQ toplam puanlarına göre sağlıklı birey özellikleri ve envanter / ölçek puanlarının karşılaştırılması

\begin{tabular}{|c|c|c|c|}
\hline & \multicolumn{2}{|c|}{ CTQ toplam puanı } & \multirow[b]{2}{*}{$\mathrm{p}$} \\
\hline & $<35(\mathrm{n}=50)$ & $\geq 35(n=15)$ & \\
\hline Yaş & $\begin{array}{c}29,5 \\
(26-35)\end{array}$ & $\begin{array}{c}24 \\
(23-31)\end{array}$ & $0,180^{*}$ \\
\hline \multicolumn{4}{|l|}{ Cinsiyet } \\
\hline $\begin{array}{l}\text { Kadın } \\
\text { Erkek }\end{array}$ & $\begin{array}{l}33(\% 66,00) \\
17(\% 34,00)\end{array}$ & $\begin{array}{l}8(\% 53,33) \\
7(\% 46,67)\end{array}$ & $0,373^{* *}$ \\
\hline \multicolumn{4}{|l|}{ Eğitim } \\
\hline İlköğretim & $1(\% 2,00)$ & $1(\% 6,67)$ & \multirow{2}{*}{$0,282^{* * * *}$} \\
\hline Lise & $13(\% 26,00)$ & $6(\% 40,00)$ & \\
\hline $\begin{array}{l}\text { Yüksek } \\
\text { lisans/Lisans } \\
\text { Çalışma } \\
\text { durumu }\end{array}$ & \multicolumn{2}{|c|}{$\begin{array}{l}\text { Çalışma } \\
\text { durumu }\end{array}$} & 0,282 \\
\hline Çalışmıyor & $20(\% 40,00)$ & $9(\% 60,00)$ & \multirow{3}{*}{$0.172^{* *}$} \\
\hline Öğrenci & $30(\% 60,00)$ & $6(\% 40,00)$ & \\
\hline Çalışıyor & $0(\% 0,00)$ & $0(\% 0,00)$ & \\
\hline \multicolumn{4}{|l|}{ Medeni durumu } \\
\hline Bekar & $24(\% 48,00)$ & $8(\% 53,33)$ & \multirow{2}{*}{$0,717^{* *}$} \\
\hline Evli & $26(\% 52,00)$ & $7(\% 46,67)$ & \\
\hline $\begin{array}{l}\text { İntihar girișimi } \\
\text { İlac tedavisi }\end{array}$ & $1(\% 2,00)$ & $1(\% 6,67)$ & $0,411^{* * * *}$ \\
\hline Yok & $8(6-10)$ & $12(10-13)$ & $0,004^{*}$ \\
\hline Antidepresan & $9(7-10)$ & $15(12-16)$ & $<0,001^{*}$ \\
\hline $\begin{array}{l}\text { Antidepresan + } \\
\text { Antipsikotik }\end{array}$ & $12(11-15)$ & $14(13-19)$ & $0,008^{*}$ \\
\hline BDÖ puanı & $8(6-10)$ & $12(10-13)$ & $0,006^{*}$ \\
\hline BAÖ puanı & $9(7-10)$ & $15(12-16)$ & $<0,001 *$ \\
\hline \multicolumn{4}{|l|}{ DERS puanı } \\
\hline Farkındalık & $12(11-15)$ & $17(13-19)$ & $0,008^{*}$ \\
\hline Açıklık & $8(6-110)$ & $14(10-13)$ & $0,006^{*}$ \\
\hline Kabullenme & $9(7-10)$ & $15(12-16)$ & $<0,001^{*}$ \\
\hline Stratejiler & $13(9-16)$ & $18(17-22)$ & $<0,001^{*}$ \\
\hline Dürtüsellik & $10(7-12)$ & $17(13-20)$ & $<0,001^{*}$ \\
\hline Amaçlar & $11(9-14)$ & $14(12-18)$ & $0,005^{*}$ \\
\hline Toplam & $62(55-74)$ & $92(86-100)$ & $<0,001^{*}$ \\
\hline $\begin{array}{l}\text { Not: Veriler, dağ } \\
\text { (1.çeyrek - 3.çeyr } \\
\text { verilmiştir. Beck } \\
\text { (BAÖ) puanı, Du } \\
\text { Çocukluk Çağı Tr }\end{array}$ & hormalliğine gör & $\begin{array}{l}\text { ürekli değişkenler } \\
\text { ler için frekans (y } \\
\text { puanı, Beck Anks } \\
\text { Ölçeği (DERS) pu } \\
\text { tistiksel anlamlı fa }\end{array}$ & $\begin{array}{l}\text { çin medyan } \\
\text { de) olarak } \\
\text { ete Ölçeği } \\
\mathrm{nl} \\
\text { a ifaden }\end{array}$ \\
\hline
\end{tabular}

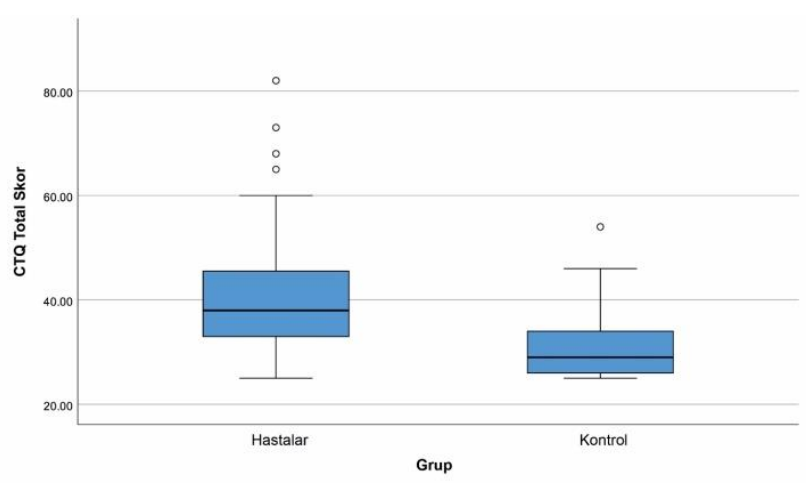

Şekil 2. Gruplara göre Çocukluk Çağı Travma Anketi (CTQ) toplam puanları

\section{TARTIŞMA VE SONUÇ}

$\mathrm{Bu}$ çalışmada da depresyon hastalarında çocukluk çağı travması varlığı ve duygu düzenleme güçlüğü ile ilişkisi değerlendirilmiştir. Depresyon hastalarında sağlıklı bireylere kıyasla çocukluk çağı travma anketi puanlarının (cinsel istismar alt boyutu hariç) ve duygu düzenleme güçlüğü ölçeği puanlarının yüksek olduğu saptanmıştır. Bununla birlikte Depresyon hastalarında CTQ toplam puanı CTQ $\geq 35$ olanlarda BDÖ ve DERS stratejiler, dürtüsellik, amaçlar alt boyutları ile toplam puanlarının yüksek olduğu saptanmıştır. Ayrıca CTQ toplam puanı ile DERS kabullenme, stratejiler, amaçlar alt boyutları ile toplam puanları arasında pozitif anlamlı ilişki saptanmıştır.

Literatürdeki çalışmalar incelendiğinde depresif bozukluk ve çocukluk çağı travmaları ilişkisini hem klinik hem de klinik olmayan örneklemde değerlendiren araştırmalar mevcuttur. Openshaw ve ark.nın yaptığı toplum bazlı çalışmaya 100 gönüllü katılımcı dahil edilmiştir. Örneklemin hayat boyu travma sayısı ortalaması 9,46 iken çocukluk çağı travma ortalaması 2,76 bulunmuştur. Katılımcıların \% 36'sı depresif bozukluk tanısı almış hayat boyu travma ve çocukluk çağı travma sayıları ile depresyon arasında pozitif yönde korelasyon saptanmıştır (24). Bizim çalışmamızda ise depresyon tanısı almış olan 63 hastadan $39(\%$ 61,90) birey 35 ve üzeri CTQ toplam puanı olduğu, 65 kişiden oluşan kontrol grubunda 15 (\% 23,08) kişi 35 ve üzeri CTQ toplam puanı olduğu saptanmıştır. Bununla birlikte çalışmamızda çocukluk çağı travması toplam puan ve duygusal istismar alt boyutu ile mevcut depresyon arasında pozitif yönde anlamlı korelasyon saptanmıştır.

Kaczmarczyk ve arkadaşlarının (25) yaptıkları 68 ilaç kullanmayan depresif bozukluk tanılı hasta ve 75 sağlıklı kontrol ile yapılan çalışmada çocukluk çağı travması depresif bozukluk tanılı hasta grubunda yüksek oranda olduğu bildirilmiştir. Aynı çalışmada çocukluk çağı travmalarının depresif bozukluktaki kognitif fonksiyonlar üzerine etkili olduğu öne sürülmüştür. $\mathrm{Yu}$ ve arkadaşlarının (26) 189 depresif bozukluk tanılı hasta ve 39 sağlıklı kontrol ile yaptığı nörogörüntüleme çalışmasında travmatik çocukluk deneyimlerinin depresif bozukluktaki sağlıksız ağ mimarisiyle bağlantılı olduğu rapor edilmiştir. 
Tablo 4. Hasta grubunda yaş ile envanter / ölçek / anket puanları arasındaki korelasyonlar

\begin{tabular}{|c|c|c|c|c|c|c|c|c|c|c|}
\hline & & \multirow[b]{2}{*}{ Yaş } & \multirow[b]{2}{*}{ BDÖ puanı } & \multirow[b]{2}{*}{ BAÖ puanı } & \multicolumn{6}{|c|}{ CTQ puanları } \\
\hline & & & & & $\begin{array}{l}\text { Duygusal } \\
\text { istismar }\end{array}$ & $\begin{array}{l}\text { Fiziksel } \\
\text { istismar }\end{array}$ & $\begin{array}{c}\text { Duygusal } \\
\text { ihmal }\end{array}$ & Fiziksel ihmal & $\begin{array}{l}\text { Cinsel } \\
\text { istismar }\end{array}$ & Toplam \\
\hline \multirow[t]{2}{*}{ Yaş } & $\mathrm{r}$ & - & $-0,367$ & $-0,267$ & $-0,349$ & $-0,167$ & $-0,072$ & 0,033 & $-0,228$ & $-0,170$ \\
\hline & $\mathrm{p}$ & - & $\mathbf{0 , 0 0 3}$ & 0,034 & 0,005 & 0,191 & 0,576 & 0,796 & 0,072 & 0,183 \\
\hline \multirow[t]{2}{*}{ BDÖ puanı } & $\mathrm{r}$ & - & - & 0,510 & 0,298 & 0,090 & 0,236 & 0,167 & 0,130 & $0, \mathbf{0 , 3 3 7}$ \\
\hline & $\mathrm{p}$ & - & - & $<0,001$ & 0,018 & 0,484 & 0,063 & 0,191 & 0,308 & $\mathbf{0 , 0 0 7}$ \\
\hline \multirow[t]{2}{*}{ BAÖ puanı } & $\mathrm{r}$ & - & - & - & 0,081 & 0,134 & 0,039 & 0,145 & 0,269 & 0,170 \\
\hline & $\mathrm{p}$ & - & - & - & 0,529 & 0,297 & 0,763 & 0,258 & $\mathbf{0 , 0 3 3}$ & 0,182 \\
\hline DERS puanı & $\mathrm{r}$ & $-0,188$ & 0,212 & 0,265 & $-0,009$ & 0,003 & 0,008 & $-0,120$ & 0,078 & 0,009 \\
\hline Farkındalık & $\mathrm{p}$ & 0,140 & 0,095 & 0,036 & 0,947 & 0,981 & 0,948 & 0,349 & 0,543 & 0,942 \\
\hline \multirow[t]{2}{*}{ Açıklık } & $\mathrm{r}$ & $-0,308$ & 0,258 & 0,234 & 0,228 & 0,163 & 0,043 & $-0,062$ & 0,322 & 0,166 \\
\hline & $\mathrm{p}$ & 0,014 & 0,041 & 0,065 & 0,073 & 0,201 & 0,736 & 0,631 & 0,010 & 0,193 \\
\hline \multirow{2}{*}{ Kabullenme } & $\mathrm{r}$ & $-0,278$ & 0,401 & 0,451 & 0,181 & 0,138 & 0,129 & 0,328 & 0,183 & 0,262 \\
\hline & $\mathrm{p}$ & $\mathbf{0 , 0 2 7}$ & $\mathbf{0 , 0 0 1}$ & $<0,001$ & 0,155 & 0,281 & 0,314 & 0,009 & 0,152 & $\mathbf{0 , 0 3 8}$ \\
\hline \multirow[t]{2}{*}{ Stratejiler } & $\mathrm{r}$ & $-0,484$ & $\mathbf{0 , 5 1 7}$ & $\mathbf{0 , 3 8 0}$ & 0,239 & 0,199 & 0,489 & 0,204 & 0,212 & 0,471 \\
\hline & $\mathrm{p}$ & $<0,001$ & $<0,001$ & 0,002 & 0,059 & 0,119 & $<0,001$ & 0,108 & 0,095 & $<0,001$ \\
\hline \multirow[t]{2}{*}{ Dürtüsellik } & $\mathrm{r}$ & $-0,414$ & $\mathbf{0 , 3 7 0}$ & 0,345 & 0,073 & 0,014 & 0,258 & 0,083 & 0,104 & 0,214 \\
\hline & $\mathrm{p}$ & $\mathbf{0 , 0 0 1}$ & $\mathbf{0 , 0 0 3}$ & 0,006 & 0,571 & 0,915 & 0,041 & 0,518 & 0,416 & 0,092 \\
\hline \multirow[t]{2}{*}{ Amaçlar } & $\mathrm{r}$ & $-0,475$ & $\mathbf{0 , 3 2 7}$ & 0,249 & 0,174 & 0,069 & 0,341 & 0,113 & 0,301 & 0,373 \\
\hline & $\mathrm{p}$ & $<0,001$ & 0,009 & 0,049 & 0,172 & 0,591 & 0,006 & 0,379 & 0,017 & 0,003 \\
\hline \multirow[t]{2}{*}{ Toplam } & $\mathrm{r}$ & $-0,527$ & 0,509 & 0,467 & 0,227 & 0,108 & 0,367 & 0,167 & 0,265 & 0,388 \\
\hline & $\mathrm{p}$ & $<0,001$ & $<0,001$ & $<0,001$ & 0,074 & 0,401 & 0,003 & 0,190 & 0,035 & 0,002 \\
\hline
\end{tabular}

Not: İstatistiksel anlamlı farkı ifaden eden değerler kalın olarak gösterilmiştir. r: Spearman korelasyon katsayısı, Beck Depresyon Ölçeği (BDÖ) puanı, Beck Anksiyete Ölçeği (BAÖ) puanı, Duygu Düzenleme Güçlüğü Ölçeği (DERS) puanı, Çocukluk Çağı Travma Anketi (CTQ). 
Bizim çalışmamızda da çocukluk çağı travmalarının depresif bozukluk hastalarında yüksek oranda olduğu ve bu hastalarda duygu düzenleme güçlüğüne (farkındalık, açıklık, kabullenme, strateji geliştirme, dürtüsellik ve amaçlar) yol açtı̆̆ saptanmıştır.

Crow ve arkadaşlarının (27) yaptıkları çalışmada çocukluktaki duygusal istismar ile mevcut depresyon arasında potansiyel bir aracı olarak duygu düzensizliğinin olduğu bildirilmiştir. Bu çalışmada aynı zamanda hem duygu düzensizliği hem de depresyon ile olan ilişkisinde diğer erken travma türlerine kıyasla çocuklukta duygusal istismarın daha büyük rolü olduğunu ve duygu düzensizliği ve duygusal istismar puanlarının mevcut depresif belirtilerdeki varyansın neredeyse yarısını açıkladığı rapor edilmiştir (27). Bizim çalışmamızda da çocukluktaki mevcut depresyon ile duygusal istismar ve duygu düzensizliği alt boyutları (açıklık, kabullenme, strateji geliştirme, dürtüsellik ve amaçlar) arasında pozitif yönde anlamlı korelasyon saptanmıştır. Bununla birlikte duygu düzensizliği ile çocuklukta duygusal ihmal ve cinsel istismar arasında daha fazla anlamlı ilişki olduğu saptanmıştır. 18-65 yaş arasındaki 802 yetişkin ile yürütülen çalışmada istismar düzeyi yüksek grubun duygu düzenlemenin tüm boyutlarında istismar düzeyi düşük olan gruba göre daha fazla güçlük yaşadığ bulgusuna ulaşılmıştır (28). Bizim çalışmamızda benzer şekilde depresyon düzeyi, duygusal ihmal ve cinsel istismar puanlarının toplam duygu düzenleme puanları ile ilişkili olduğunu gözlemledik.

Çalışmamızın bazı kısıtlılıkları bulunmaktadır. Birincisi katılımcıların tedavi öykülerinin ayrıntılı biçimde değerlendirilmemiş olması, hastaların uzun süreli izlenmemesi, geçmiş hastalık dönemleriyle ilgili bir değerlendirme yapılmamış olması ve kesitsel olmasıdır. İkincisi kullanılan ölçeklerin öz bildirime dayalı ölçekler olması, örneklemin küçük olması çalışmamızın diğer kısıtlılıkları arasındandır.

Sonuç olarak çalışmamız çocukluk çağı travmalarına maruz kalma durumunun mevcut depresyonla ilişkili olduğu ve bu durumun duygu düzenlemede güçlüklere neden olduğunu gösterdi. Dolayısıyla depresyon hastalarında duygu düzenleme güçlüğünün nedenlerinden birisinin çocukluk çağı travması olabileceği göz önünde bulundurularak yeni tedavi stratejilerinin ve terapilerinin geliştirilmesi gerektiği düşünülmektedir. Elde edilen bu sonuçların, daha geniş katılımlı hasta gruplarıyla desteklenmesi ve gelecek çalışmalara öncülük etmesini temenni ediyoruz.

Yazarların Katkıları: Fikir/Kavram: R.A.; Tasarım: R.A., O.K.; Veri Toplama ve/veya İşleme: O.K.; Analiz ve/veya Yorum: R.A., O.K.; Literatür Taraması: R.A., O.K.; Makale Yazımı: R.A., O.K.; Eleştirel İnceleme: R.A., O.K.

\section{KAYNAKLAR}

1. Kilincel S, Vural AP, Kilincel O. Theory of mind deficit in adolescents with major depressive disorder. Anadolu Psikiyatri Derg. 2020; 21(2): 158-64.

2. Uher R. Gene-environment interactions in severe mental illness. Front Psychiatry. 2014;5(3):48.

3. Brietzke E, Kauer Sant'anna M, Jackowski A, GrassiOliveira R, Bucker J, Zugman A, et al. Impact of childhood stress on psychopathology. Braz J Psychiatry. 2012;34(4):480-8.

4. Bouras G, Lazaratou E. Emergence of early childhood trauma in adult psychiatric symptomatology. Psychiatriki. 2012; 23(Suppl 1):39-48.

5. Cross D, Crow T, Powers A, Bradley B. Childhood trauma, PTSD, and problematic alcohol and substance use in low-income, African-American men and women. Child Abuse Negl. 2015;44:26-35.

6. Ay R, Erbay LG. Relationship between childhood trauma and suicide probability in obsessivecompulsive disorder. Psychiatry Res. 2018;261:132-6.

7. Taner Y, Gökler B. Çocuk istismarı ve ihmali: Psikiyatrik yönleri. Acta Medica. 2004;35(2):82-6.

8. Brown GR, Anderson B. Psychiatric morbidity in adult inpatients with childhood histories of sexual and physical abuse. Am J Psychiatry. 1991;148(1):55-61.

9. Walker E, Katon W, Harrop-Griffiths J, Holm L, Russo J, Hickok LR. Relationship of chronic pelvic pain to psychiatric diagnoses and childhood sexual abuse. Am J Psychiatry. 1988;145(1):75-80.

10. Dakil SR, Cox M, Lin H, Flores G. Racial and ethnic disparities in physical abuse reporting and child protective services interventions in the United States. J Natl Med Assoc. 2011;103(9-10):926-31.

11. Yurdakök K, İnce O. Duygusal istismar ve ihmal. Katk1 Pediatri Dergisi. 2010;32(4):423-33.

12. Hopfinger L, Berking M, Bockting CL, Ebert DD. Emotion regulation mediates the effect of childhood trauma on depression. J Affect Disord. 2016;198:18997.

13. Gross JJ. Emotion regulation: taking stock and moving forward. Emotion. 2013;13(3):359-65.

14. Gratz KL, Roemer L. Multidimensional assessment of emotion regulation and dysregulation: Development, factor structure, and initial validation of the difficulties in emotion regulation scale. Journal of Psychopathology and Behavioral Assessment. 2004;26(1):41-54.

15. Weiss NH, Nelson RJ, Contractor AA, Sullivan TP. Emotion dysregulation and posttraumatic stress disorder: a test of the incremental role of difficulties regulating positive emotions. Anxiety Stress Coping. 2019;32(4):443-56.

16. McLaughlin KA, Greif Green J, Gruber MJ, Sampson NA, Zaslavsky AM, Kessler RC. Childhood adversities and first onset of psychiatric disorders in a national sample of US adolescents. Arch Gen Psychiatry. 2012;69(11):1151-60.

17. Beck AT, Ward CH, Mendelson M, Mock J, Erbaugh J. An inventory for measuring depression. Arch Gen Psychiatry. 1961;4(6):561-71.

18. Hisli N. A reliability and validity study of Beck Depression Inventory in a university student sample. J Psychol. 1989;7(1):3-13.

19. Beck AT, Epstein N, Brown G, Steer RA. An inventory for measuring clinical anxiety: psychometric properties. J Consult Clin Psychol. 1988;56(6):893-7.

20. Ulusoy M, Sahin NH, Erkmen H. The Beck anxiety inventory: psychometric properties. J Cogn Psychother. 1998;12(2):163-72. 
21. Bernstein DP, Stein JA, Newcomb MD, Walker E, Pogge D, Ahluvalia T, et al. Development and validation of a brief screening version of the Childhood Trauma Questionnaire. Child Abuse Negl. 2003;27(2):169-90.

22. Şar V, Öztürk PE, İkikardeş E. Çocukluk çağı ruhsal travma ölçeğinin Türkçe uyarlamasının geçerlilik ve güvenilirliği. Türkiye Klinikleri Tıp Bilimleri Dergisi. 2012;32(4):1054-63.

23. Ruganci RN, Gencoz T. Psychometric properties of a Turkish version of the Difficulties in Emotion Regulation Scale. J Clin Psychol. 2010;66(4):442-55.

24. Openshaw M, Thompson LM, de Pheils PB, Mendoza-Flores ME, Humphreys J. Childhood trauma is associated with depressive symptoms in Mexico City women. Rev Panam Salud Publica. 2015;37(4-5):308-15.

25. Kaczmarczyk M, Wingenfeld K, Kuehl LK, Otte C, Hinkelmann K. Childhood trauma and diagnosis of major depression: Association with memory and executive function. Psychiatry Res. 2018;270:880-6.

26. Yu M, Linn KA, Shinohara RT, Oathes DJ, Cook PA, Duprat R, et al. Childhood trauma history is linked to abnormal brain connectivity in major depression. Proc Natl Acad Sci. 2019;116(17):8582-90.

27. Crow T, Cross D, Powers A, Bradley B. Emotion dysregulation as a mediator between childhood emotional abuse and current depression in a lowincome African-American sample. Child Abuse Negl. 2014;38(10):1590-8.

28. Yılmaz B. Çocukluk çağı örselenme yaşantıları: Duygu düzenleme, kişilerarası tarz ve genel psikolojik sağlık açısından bir inceleme [Uzmanlık tezi]. Ankara: Ankara Üniversitesi Sosyal Bilimler Enstitüsü Psikoloji Anabilim Dalı; 2012. 